\title{
Why do peer-to-peer (P2P) lending platforms fail? The gap between P2P lenders' preferences and the platforms' intentions
}

\author{
Galit Klein $^{1} \oplus \cdot$ Zeev Shtudiner $^{1}\left[\right.$ Moti $^{-}$zwilling $^{1}$
}

Accepted: 25 May 2021

(c) The Author(s), under exclusive licence to Springer Science+Business Media, LLC, part of Springer Nature 2021

\begin{abstract}
In the current study, we examine why peer-to-peer (P2P) lending platforms play only a minor role in the finance industry in Israel, compared to the traditional banking system. We conducted two studies and attempted to discover if a discrepancy exists between the lenders' preferences and the platforms' incentives. In the first study, we conducted a conjoint analysis to examine the impact of lenders' decisions to invest through P2P platforms. The second study examines the factors in which platforms use to determine the lending interest rate for loans. We found that although lenders wish to decrease their risk and guarantee their investment, P2P companies encourage riskier borrowers. This contradiction between the priorities of the lenders and those of the platforms may explain why the non-users consider P2P lending to be a high risk. We offer several suggestions to increase the attractiveness of the Fintech and lending platforms industry.
\end{abstract}

Keywords P2P lending platforms · Investments · Lenders · Finance institutions · Fintech

\section{Introduction}

Peer-to-peer (P2P) lending platforms are online and direct financial transaction platforms that allow lenders, often referred to as "investors," to lend money to individuals or small enterprises. The companies that operate the platforms serve as a mediator

Galit Klein

galitk@ariel.ac.il

Zeev Shtudiner

zeevs@ariel.ac.il

Moti Zwilling

motiz@ariel.ac.il

1 The Department of Economic and Business Administration, Ariel University, Ariel, Israel 
between the two parties, and have limited responsibility for any damage or loss resulting from the transaction process [10]. Contrary to direct financial transaction systems (i.e., P2P platforms), banks and other more traditional institutions serve as indirect financial intermediaries. Financial indirect intermediaries perform the role of denomination, information, liquidity, maturity, and risk intermediations between borrowers and lenders. Direct financial companies, such as P2P platforms, eliminate the need for intermediaries, since they connect the lenders and the borrower directly, in the sense that the contract between the lender and the borrower involves only them, leaving out the platform entirely [10].

As part of the Fintech sector, the companies' main competency is their ability to screen and detect potential risks posed by borrowers, based on big data and algorithm analyses [9]. While it was hoped that these platforms would create a change in the lending market, similar to that of digital banking [18], the P2P sector plays only a minor role in the Israeli finance industry, with less than a $4 \%$ market share [28], and approximately $10-12 \%$ of the worldwide market [27]. Our motivation in the current study is to explore whether the reason for the small market share is part of a discrepancy that exists between the lenders' preference for low-risk loans, and the P2P companies' preference to encourage riskier loans in order to attract borrowers. Thus, we ask the following question: Is there a gap between lenders' preferences and P2P companies' behavior?

To understand why P2P lending platforms occupies only a minor share of the market, we conducted two studies. Each study examines a different side of the dyadic connection between lenders' preferences and the P2P companies' behavior. In the first study, we investigated which attributes have a higher utility for lenders, and the most impact on their decision to invest through P2P platforms. We also compared the perceptions of the lenders to those of the non-users (people who are not using P2P lending platforms), in order to understand whether the two groups have similar or different preferences when it comes to P2P companies. In the second study, we focused on the $\mathrm{P} 2 \mathrm{P}$ companies, and examined how they determine the interest rate for loans, other than considering the borrowers' financial condition. The aim of the current study is to understand if the companies consider the lenders' preferences regarding optimal loan attributes.

The combined results of these studies show a discrepancy between the lenders' priorities and the platforms' behavior. While the lenders seek to reduce the dangers related to giving high-risk loans, the platforms are more attuned to attracting borrowers. As such, they do not consider the purpose of the loan, and often encourage expensiveeven risky-loans. This gap may explain why the non-users avoids investing through P2P platforms, and why the government is failing in its attempt to encourage competition in the banking industry. 


\section{Literature review}

\subsection{The P2P mechanism}

Peer-to-peer lending companies are financial platforms that connect two parties: "borrowers" who request loans, and "lenders" (or "investors") who lend money, without the intervention of an intermediary body, e.g., traditional banks. Contrary to the banking system, which serves as an indirect financial system, P2P platforms allow individuals or small businesses to raise funds directly from the borrowers. As a substitute for an indirect financial system, such as a bank, these companies offer an internet platform that minimizes risk by spreading investments amongst multiple borrowers and filtering investors based on several criteria. Being Internet-based helps the companies reduce costs, compared to the traditional banking systems [20]. Unlike banks, most P2P companies have a limited number of human resources (up to 5 in most cases), and a small number of offices and operation headquarters. The fact that $\mathrm{P} 2 \mathrm{P}$ and banking do not rely on the same monitoring technology or regulation, may contribute to the ability of $\mathrm{P} 2 \mathrm{P}$ platforms to present attractive loan rates for individuals and small firms. This said, the main advantage of P2P companies is their ability to extract knowledge regarding borrowers from the Internet, which may not be obvious to the traditional and indirect system. For example, P2P companies extract information from social networking systems (e.g., Facebook, Instagram) about potential risks, e.g., if the borrower is a diligent person, if this person has a routine life pattern, personality type (e.g., risk averse or risk-taker), etc. Extracting information about the borrower that may indicate the borrower's potential risk level is, in fact, the core capability of these platforms.

Following the financial world crisis in 2008, many people around the world lost trust in the banking systems. This phenomenon motivated people to search for alternative services that had previously been perceived as being solely provided by banks-such as giving loans. Although a substantial time has passed since the emergence of the first P2P platform, named "Zopa" in the UK in 2005, the percentage of P2P platforms in the lending market, according to Milne [17], is still relatively low. For example, P2Ps have less than a $2 \%$ market share in the UK and the US, compared to conventional alternatives. ${ }^{1}$ Nevertheless, it was found that many new $\mathrm{P} 2 \mathrm{P}$ platforms have been established over the past decade around the world, and it is a growing industry. It has continued to grow during the COVID-19 pandemic and is expected to continue to develop in the coming years. ${ }^{2}$

The establishment of the first P2P firm in Israel encouraged the appearance of additional $\mathrm{P} 2 \mathrm{P}$ companies, which are divided into two main categories according to loan sector: Private and Business [2, 32]. At the time of the study, four P2P lending companies were operating in Israel. The first Israeli P2P platform was established in 2012 (Eloan), followed by three more companies - B2B, Tarya, and Blender. B2B is oriented primarily toward loans for the industrial sector, while the other three

\footnotetext{
1 http://www.disruptivefinance.co.uk/2014/03/15/what-is-the-market-size-of-peer-to-peer-finance/.

2 https://www.maximizemarketresearch.com/market-report/global-peer-to-peer-lending-market/54358/.
} 
companies target the private sector. Managers in the industry estimate that $\mathrm{P} 2 \mathrm{P}$ companies have an approximately $4 \%$ market share in the Israeli lending market.

Investors can invest in the platform using one of three mechanisms. The first allows them to select borrowers directly from a list that includes various details about the borrower's profile and the loan conditions. These details include age, gender, occupation, and the purpose of the loan, but the borrowers' identity remains confidential. Some of the Israeli companies, such as Blender and eLoan, enable lenders to be exposed to an anonymous and confidential borrowers' list detailed with borrowers' demographic information. However, to minimize the lenders' risk, Israeli P2P firms do not allow a lender to lend a single loan to a single person. Instead, the loan is divided and given to a group of multiple borrowers. The second option asks the lenders to specify, in advance, the characteristics that are significant for them. Based on these characteristics, the platform suggests a list of potential borrowers, and the investor manually or automatically selects potential borrowers. A third option, which is quite common among many lenders in Israeli platforms, is automatic without the lender's intervention. The investor specifies the amount of risk (interest rate), and the investment period. The platform then selects the borrowers, and distributes the investment capital according to the platform's policy. Using this mechanism, lenders do not see the characteristics of the borrowers to whom they are lending, and know nothing of their risk level, other than the interest rate. This approach, which is similar to many global P2P firms, such as Smava (Germany), was found in the Israeli P2P firm named Tarya.

\subsection{The factors that affect P2P lenders' decisions}

Studies that examine the decision-making processes of $\mathrm{P} 2 \mathrm{P}$ lenders do not invest hastily. They prefer to avoid high risk investments and apply rational economic considerations, and search for economic information about the borrowers, such as their debt/income levels, home ownership, employment status, etc. [4]. However, despite their attempt to adhere to rational processes, lenders are also influenced by perceptual and irrational signals, such as the borrowers' gender, ethnicity, number of friends, and even their physical attractiveness [4, 5, 13, 14]. Relying on signals that are not necessarily rational, was found in previous studies [1, 8, 13, 14], showing that factors such as cultural distance, institutional environment, and even language can affect institutional investors.

Since P2P companies resemble crowdfunding platforms, several scholars [16, 27] suggested that investors' behaviors are partially influenced by "herd" behaviors, and depend on their network connections. For example, Zhang and Liu [29] found that lenders showed rational herding behaviors, and that these behaviors showed affirmative consequences, compared to irrational behaviors. Liu et al. [16] introduced a new concept called "relational herding". This term refers to lenders' higher tendency to follow offline friends' behavior than the behavior of their online friends or strangers.

The need to rely on irrational behaviors, herd behaviors, or perceptual signals partially stems from the problem of asymmetric information [21]. While the borrowers have all of the relevant information about their true ability to return the loan, the 
lenders have only minimal information about the borrowers' true condition. Therefore, they respond based on the information provided by the P2P platform regarding the borrowers' details, and are dependent on the company's ability to attract reliable borrowers, vet them thoroughly, and filter out those who are untrustworthy. The problem of asymmetric information can decrease the amount of trust lenders have in the P2P platform's ability to protect their investment. After all, the contract between the lender and the borrower does not include the P2P company, so that all losses are borne solely by the lender, not by the platform that served as an intermediary between the parties. As such, we can assume that when looking for the optimal investment (a loan), lenders will prefer to reduce their hazards, and search for attributions that indicate a low-risk loan. Therefore, our first hypothesis is as follows:

H1: Lenders will prefer loans that have low-risk attributions.

\subsection{The role of the P2P lending platforms in determining interest rates}

P2P lending platforms are considered a two-sided market, connecting lenders and borrowers. The companies that facilitate the transactions in this market serve as intermediary financial brokerages, which match lenders' supply and borrowers' demand, based on the needs of the borrowers and the risk acceptable to the lenders [9]. Unlike banks and other traditional finance institutions, P2P platforms are not considered part of the contract, and take no responsibility for the transaction or for any loss incurred as a result of unpaid loans (defaults). Their main value is their ability to connect the two parties, and their expertise in screening high-risk borrowers, who are signaled for the investors by their interest rate; a higher interest rate indicates greater risk. Nevertheless, as for-profit corporations, P2P companies' main desire is to increase their profits. Thus, while the lenders may desire to reduce hazard loans, the company may have other interests, such as encouraging borrowers to loan higher amounts of money. To encourage borrowers, the company needs to offer attractive interest rates, but this may create a conflict of interest with the lenders, who desire to gain higher interest rates on riskier loans. The second study aims to reveal some of the criteria that $\mathrm{P} 2 \mathrm{P}$ platforms use to determine interest rates, whether the rates truly capture riskier borrowers, and if they are congruent with the lenders' preferences.

Prior studies indicate that in order to determine the expected interest rate for a loan, companies rely primarily on financial variables [4, 12]. Klafft [12] argued that the rules used by $\mathrm{P} 2 \mathrm{P}$ companies to classify potential borrowers are similar to the criteria used by banks and other financial institutions. Based on Prosper's data base, Klafft [12] found that the central variable that affected the interest rate was the borrower's credit rating, while ratio of expenditure to income had a low, but significant effect. Other variables, such as the existence of a bank account or ownership of an apartment, had no effect on determining the interest rate.

Other studies also indicated that besides the financial statements, "soft" elements - including borrowers' demographic characteristics and appearance-also affect the interest rates for loans [5, 18]. For example, Pope and Sydnor [20] found that the most attractive borrowers were white males, aged 35-60. Single women paid 
$0.4 \%$ lower interest rates than men, although their repayment rates (default) were $2 \%$ lower than those of men [20]. Ravina [21] found that African American borrowers paid between 139 and 146 more interest points than white borrowers, meaning they were charged between $1.39 \%$ and $1.46 \%$ higher interest rates for the same loan.

To understand how P2P companies determine their interest rates, we conducted qualitative interviews with six of the leading managers (CEOs and founders) in four Israeli P2P companies, which account for most of the market. Most of the senior executives who we interviewed confirmed that the screening process is usually dependent on financial information provided voluntarily by the borrowers or taken from an open source. However, they also rely on knowledge and techniques that were developed by the intelligence forces. The interviewees claimed that they combine financial information with data gathered from non-financial sources, such as social networks. In addition, a CEO whom we interviewed also stated that he categorizes borrowers' portfolios based on behavioral biometric patterns, such as the speed they type at and the patterns of their mouse clicks. This categorization is carried out for two purposes: 1 . To authenticate the borrowers each time they interact with the platform and maintain their privacy; and 2. To track their activities with the platform and extract knowledge in order to achieve better portfolio tuning and adjustment to lenders' requests and obstacles.

The interest rate should also compensate for the problem of moral hazard, when borrowers are given a loan, but refuse to return the debt $[3,9]$. Due to consumer protection laws, it is difficult for lenders to contact borrowers directly, even in the case of a default. P2P platforms do not enable the lenders to directly interact with borrowers through the system, based on legal terms and privacy policies. Information about the borrower will be visible to the lender only if the lender sues the borrower. For example, as Hidayat et al. [10] showed, in Indonesia, in the case of loan default, the P2P lender is not allowed to directly contact the borrower before a 90-day default limit has passed. Moreover, basic human rights ensure borrowers the right not to be harassed by the lender agencies, as determined by the Reserve Bank of India ${ }^{1}{ }^{3}$ These terms may increase the problem of moral hazard by the lenders, as the P2P lenders expect the company to give a higher interest rate in the case of hazard loans. However, this can produce a question of loyalty. On the one hand, the company may desire to encourage the lenders to invest by reducing moral hazard (i.e. high interest for high risk loans). On the other hand, the company wishes to increase its own revenues by attracting more borrowers-including riskier borrowers-by providing attractive interest rates. Indeed, when we asked one of the founders how he recruits lenders, he replied that he does not need to recruit them because there is a large supply of lenders interested in investing through the P2P platform; rather, he focuses his marketing efforts on recruiting quality borrowers. Having a large supply of investors and no direct responsibility for the investors' losses, it only makes sense that the company will prefer the interest of the borrowers, in some way, at the expense

\footnotetext{
${ }^{3}$ https://economictimes.indiatimes.com/wealth/borrow/five-rights-of-loan-defaulters/articleshow/51752 696.cms?from $=$ mdr.
} 
of the loaners' preferences for low-risk loans. Therefore, our second hypothesis is as follows:

H2: There is a gap between the P2P companies' incentive and the lenders' preferences to reduce the risks of the loans.

In summary, P2P platforms use various methods to attract lenders and reduce their concern about borrowers' trustworthiness. In the current study, we compare lenders' order of preferences with the way these companies behave when setting the interest rate. The first study will explore which attributes are more significant and have a greater influence on the lenders' decision-making process. Whereas, previous studies mostly analyzed lenders using a retrospective method [i.e., 5, 18-21], the current study addresses this question from another point of viewexamining not only the factors that lenders report as influencing their decisionmaking, but also their order of preferences. This enables us to evaluate the factors that have the most impact on lenders' decision making, and which factors are negligible in their eyes. The second study shifts the research focus to the companies, and examines whether they take into consideration the lenders' preferences, which indicates if they are interested in benefiting the lenders or the borrowers. To answer this question, we evaluated the distribution of loans, and then compared the companies' behavior with the lenders' preferences, as measured in the first study. We also examined whether the purpose of the loan and additional demographic characteristics have an impact on the interest rate. Since the companies that operate in Israel determine the interest rate in advance, determining the interest rate is considered a constant variable that signals the loan's level of risk. Although, most companies neither the variables nor the process for determining the level of risk are transparent to the public, however, one company did have an open access database concerning some of the borrowers, and the loan attributes they were seeking. Based on this database, the second study examines the impact of characteristics that signal hazard, other than borrower's financial condition, on the interest rate.

\section{Study 1: Ranking the attributes that affect lenders' decisions}

The purpose of the first study was to understand which attributes are most important to lenders, and therefore influence their decision to invest through P2P platforms, To evaluate their preferences, we conducted an adaptive conjoint analysis of a group of P2P's lenders. Contrary to more sophisticated investment tools, such as the stock market, P2P investments are geared toward the general public, which is comprised of people who are not necessarily investment experts. Relying on the Internet, P2P companies try to help lenders by making the lending process easier for less sophisticated investors, so that they can make direct investments without the aid of expert financial advisors. Concomitantly, we conducted a similar analysis among the non-users (from the general public) to investigate their preferences when using P2P platforms. 


\subsection{Methodology}

\subsubsection{Sample}

We conducted an adaptive conjoint analysis procedure among lenders, who are registered with one of the largest P2P platforms in Israel. In order to recruit lenders for the study, we asked the company to send a message to all its lenders, with an explanation about the purpose of the research, accompanied by a link to a questionnaire. The company re-sent the invitation again a month later. The researchers did not have access to any identifying details about the respondents, and the company did not have knowledge about who responded to our request. Therefore, full anonymity was maintained.

According to the company's executives, more than 6000 investors are registered with the platform. Of these, 240 agreed to answer the questionnaire, but only 72 actually completed it, and were included in the final analysis for a response rate of approximately $1.5 \%$. A majority $(80 \%)$ of the respondents were male. Their age ranged from 20 to 74 years, and the average age was $46(\mathrm{SD}=15.44)$. Most respondents were married $(51 \%), 22 \%$ were single, and the rest were either widowed or divorced (5\%). The income of $25 \%$ was below average; $15 \%$ reported an average income, and $60 \%$ had an above-average income. Most respondents had a college education (77\%) and the rest had a secondary or other education; $31 \%$ of the respondents had a degree in economics or in a related field, and about $18 \%$ of the respondents worked in a field related to economics.

A similar questionnaire was completed by a group of 81 respondents from the general public (non-users). Of these respondents, 51\% were male. Respondents' ages ranged from 20 to 76 years, and the mean age was $36(\mathrm{SD}=13.97)$; two-thirds (66\%) were married; $30 \%$ were single; and the rest (4\%) were widowed or divorced. Regarding income, $43 \%$ of the non-users respondents had a below-average income; $16 \%$ had an average income, and $41 \%$ had an above-average income. Most respondents $(86 \%)$ had a college education; the rest had a secondary or other education. Approximately $30 \%$ of the respondents held a college degree in economics or a related field, and $24 \%$ worked in a field related to economics.

\subsubsection{Procedure: adaptive choice-based conjoint method}

We examined lenders' preferences using the adaptive choice-based conjoint (ACBC) method, which requires the respondents to choose from among several options, in retry trials. In each trial, the respondent chooses between two or more options, with similar attributes, but at different levels. The repeated trials reveal respondents' ordered preferences profile-from the most important attributes to the least and most negligible ones [7, 24]. The conjoint analysis model assumes that consumers wish to make a rational choice, and maximize their utility. Therefore, when choosing from among a variety of options, they prefer the optimal option that will maximize their utility. However, since optimal options seldom exist, people eventually have to opt for suboptimal options. The final choice shows, indirectly, the attributes that are the most importance for the respondents, 
the points on which they will not compromise, unlike attributes that are less important. We prepared the conjoint analysis with the assistance of Conjoint. ly software, which uses Markov chain Monte Carlo Hierarchical Bayes (MCMC HB) estimation to calculate individual-level coefficients.

The results of the research present the utility and values that respondents assign to each attribute of the loans on the P2P platform. The utility of an attribute is its relative value, for the respondent, compared to other attributes; the higher an attribute's relative value, the more important it is to that person, and the stronger its impact on the decision-making process $[23,24]$. In the current study, those attributes with higher values have a greater impact on lenders' decisions about whether or not to invest money through P2P platforms.

The loan attributes were as follows: Interest rate: indicative of the risk level embedded in the loan; Distribution: procedure for loan dispersal; Purpose: objective for which the loan is requested; Sinking fund: if the platform offers an option can return an unpaid loan; Duration: duration of the loan; Information: type of information about borrowers that is available to lenders. Each attribute had at least two levels (e.g., for the "security sinking option" the levels were "exist" or "not-exist"). Table 1 displays the attributes and the levels for each one.

The respondents received an invitation to participate in the study. Clicking on a link in the invitation opened a screen displaying two loan option scenarios, from which the lenders were asked to choose their preferred scenario. The loans had identical attributes, but there were differences in the level of each attribute. The selection process was repeated eight times; the attributes remained unchanged but had) different levels in each trial. Figure 1 shows an example of one screen from the research site.

During the retrials, the program was able to "learn" the respondents' preferences and narrowed the differences between the loan options, to focus on the subject's preferred parameters. At the end of eight iterations, the different attributes were ranked

\begin{tabular}{|c|c|c|}
\hline \multicolumn{2}{|c|}{ Which of the following loans would you choose ? } \\
\hline Loan Type & New Business & Existing Business \\
\hline Demographic data on borrower & Age, Sex, \# of Children & $\begin{array}{c}\text { Age, Sex, \# of Children, Financial Sta- } \\
\text { tus }\end{array}$ \\
\hline Security Fund & Exist & Not Exist \\
\hline Level of risk & High & Medium \\
\hline Loan Period & $2-12$ Months & Above 1 Year, Max 2 Years \\
\hline Loan Distribution & Automatic By System & ers \\
\hline & CHOOSE & CHOOSE \\
\hline
\end{tabular}

Fig. 1 Sample screen in the questionnaire 


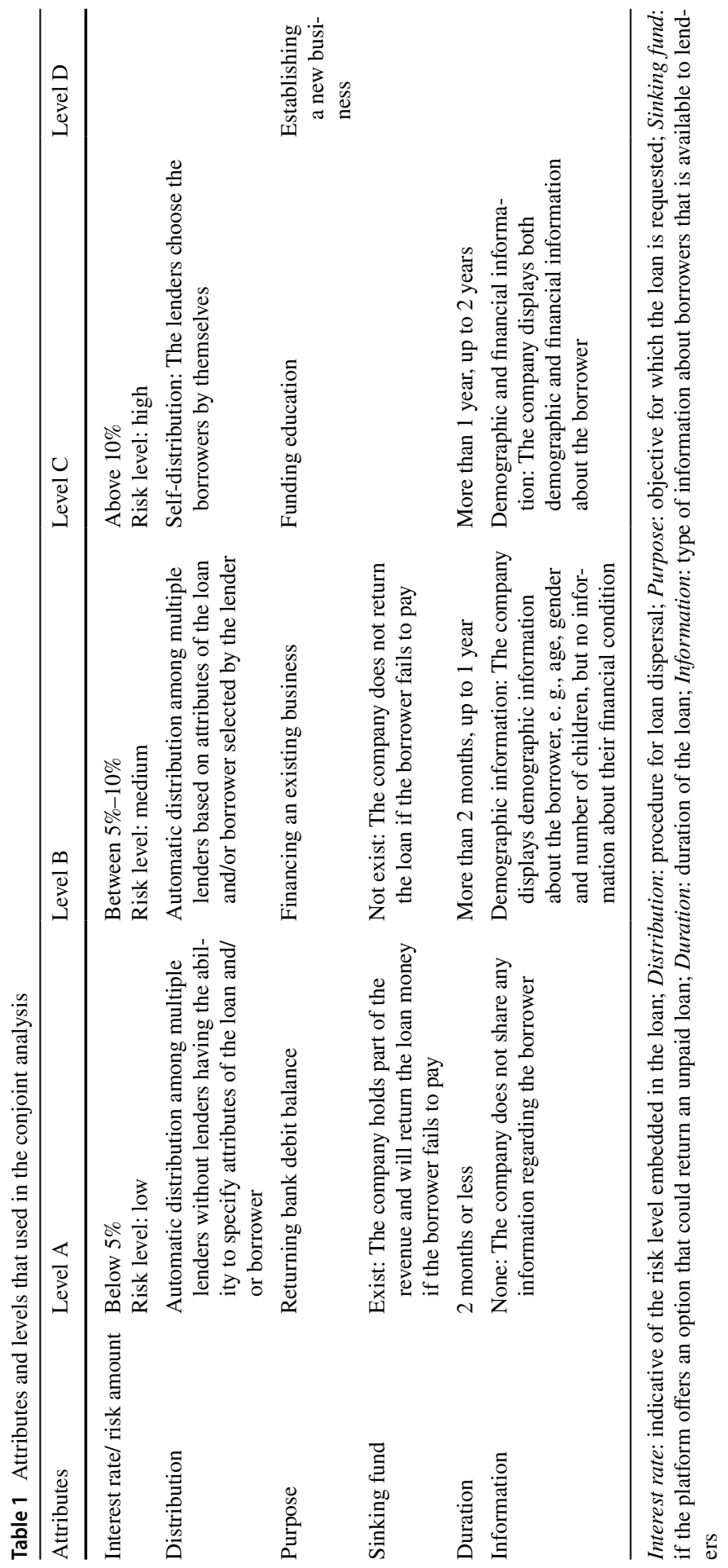


according to their utility for the subject. Each attribute was given a different weight, indicating the degree of preference compared to other attributes, such that the sum total of weights was 100 . The software also calculated the weight of the different levels of each attribute, and the direction of this level in the subject's decision to invest or not.

\subsubsection{Attitudes about using P2P platforms}

To understand lenders' attitudes about P2P platforms, we asked them several questions regarding: (a) the extent to which the loan amount is significant to the lender (on a scale of 1-insignificant to 7-significant); (b) the amount of money the lender is willing to lend through the platform; (c) the percentage of interest which the lender wants to gain from the loan; (d) satisfaction with the use of the platform (on a scale of 1-extremely unsatisfied to 7-very satisfied); (e) the extent to which using the platform met the lender's expectations (on a scale of 1-very far from meeting them to 7-definitely met them); and (f) the degree of risk in using the platform (on a scale of 1 -very low risk to 7 -very high risk).

\subsection{Results}

The conjoint analysis revealed respondents' preferences and their weights, as shown in Fig. 2, which displays the distribution of attributes and mean attribution preferences for the lenders and for the non-users. Asterisks indicate that the differences between the means of the two groups are significant, based on independent sample T-test analysis.

According to conjoint analysis results, the highest utility for the lenders was the existence of a sinking fund. The second highest utility was the purpose of the loan, followed by the amount of information provided about the borrower, the

Fig. 2 Mean weight of loan attributes for lenders and general public

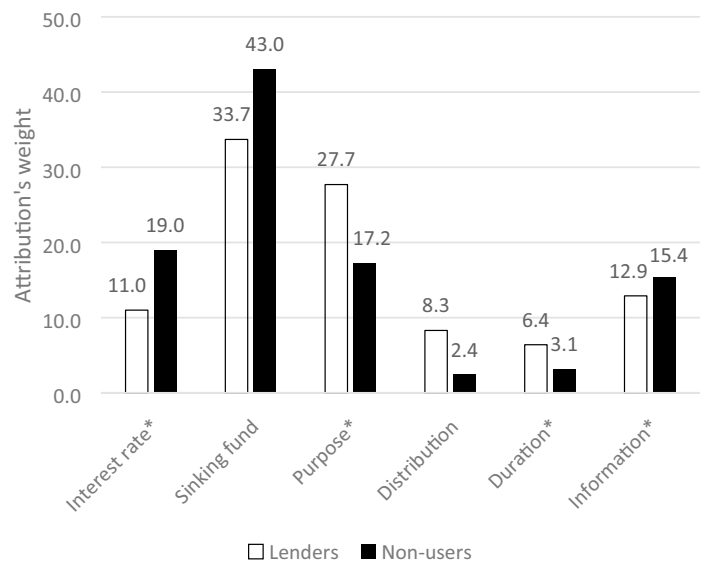


level of the loan risk (interest rate), the distribution of the loan and, lastly duration, which had the lowest impact on the lenders' decision-making process.

The utility rankings among the non-users were slightly different. Similar to the lenders, the existence of a sinking fund was the most important variable for this group. The second most important attribute, however, was the interest rate, which represents the loan's risk level, followed by the purpose of the loan, the amount of information provided about the borrower, the duration of the loan period, and lastly, how the loan was distributed.

To compare between the ranked importance of attributes for lenders and for the non-users, an independent-sample T-test analysis was conducted. A significant difference was found in the risk level attributes $(\mathrm{t}(129)=2.35, p<0.05)$. The non-users put more weight on risk attributes $(M=18.46, S D=12.66)$ than lenders $(M=14.49$, $\mathrm{SD}=6.02)$. A significant difference was also found with respect to the purpose of the loan $(\mathrm{t}(129)=6.20, p<0.01)$, with lenders giving more weight to the purpose of the loan $(\mathrm{M}=27.40, \mathrm{SD}=9.0)$ than the non-users $(\mathrm{M}=18.31, \mathrm{SD}=7.29)$. Moreover, a significant difference was found for the duration of the loan period $(\mathrm{t}(129)=1.92$, $p<0.05)$. The non-users gave more weight to the duration of the loan $(\mathrm{M}=12.76$, $\mathrm{SD}=7.68)$ than the lenders $(\mathrm{M}=10.44, \mathrm{SD}=6.04)$. Finally, differences close to significance were found with respect to information about the borrower $(\mathrm{t}(129)=1.86$, $p<0.07)$. The non-users gave more weight to this attribute $(\mathrm{M}=15.41, \mathrm{SD}=6.15)$ than the lenders $(\mathrm{M}=12.93, \mathrm{SD}=8.50)$. In short, with the exception of the purpose of the loan, the differences indicate that the non-users is more attuned to earning revenues and less attuned to risk compared to the lenders.

\subsubsection{Differences in the importance of attributes}

Using conjoint analysis, we measured the differences in the importance of each attribute for the lenders. A positive score indicated that the attribute at this level contributes positively to lenders' decision to invest their money, while a negative score meant that this level of the attribute would decrease its utility, and lower the lender's likelihood to invest. Figure 3 displays the results of this analysis.

The results regarding the lenders' preferences indicated that they prefer a medium amount of risk (5\%-10\% interest rate), over either low-risk loans (interest rate $<5 \%$ ) or high-risk loans ( $>10 \%$ interest rate). Lenders also preferred loans with sinking funds over those without the possibility of recouping an unpaid loan. With regard to the purpose of the loan, lenders preferred loans intended to fund higher education, establish a new business, or finance an existing one. Conversely, loans taken in order to pay off a bank debit balance gained a negative score, indicating that lenders prefer not to invest money for this purpose. As such, the results confirm our first hypothesis - that lenders will prefer low-risk loans. Looking at the distribution technique, we see that lenders prefer an automatic distribution method based on criteria set by the lender. Self-distribution or automatic distribution without the ability to determine definite criteria reduced lenders' tendency to invest in the P2P platform. Although the duration of the loan had a slight effect on the loan's attractiveness, lenders preferred longer-term loans (over two months) and preferred to avoid shortterm loans. Finally, we found that lenders preferred loans that revealed information 


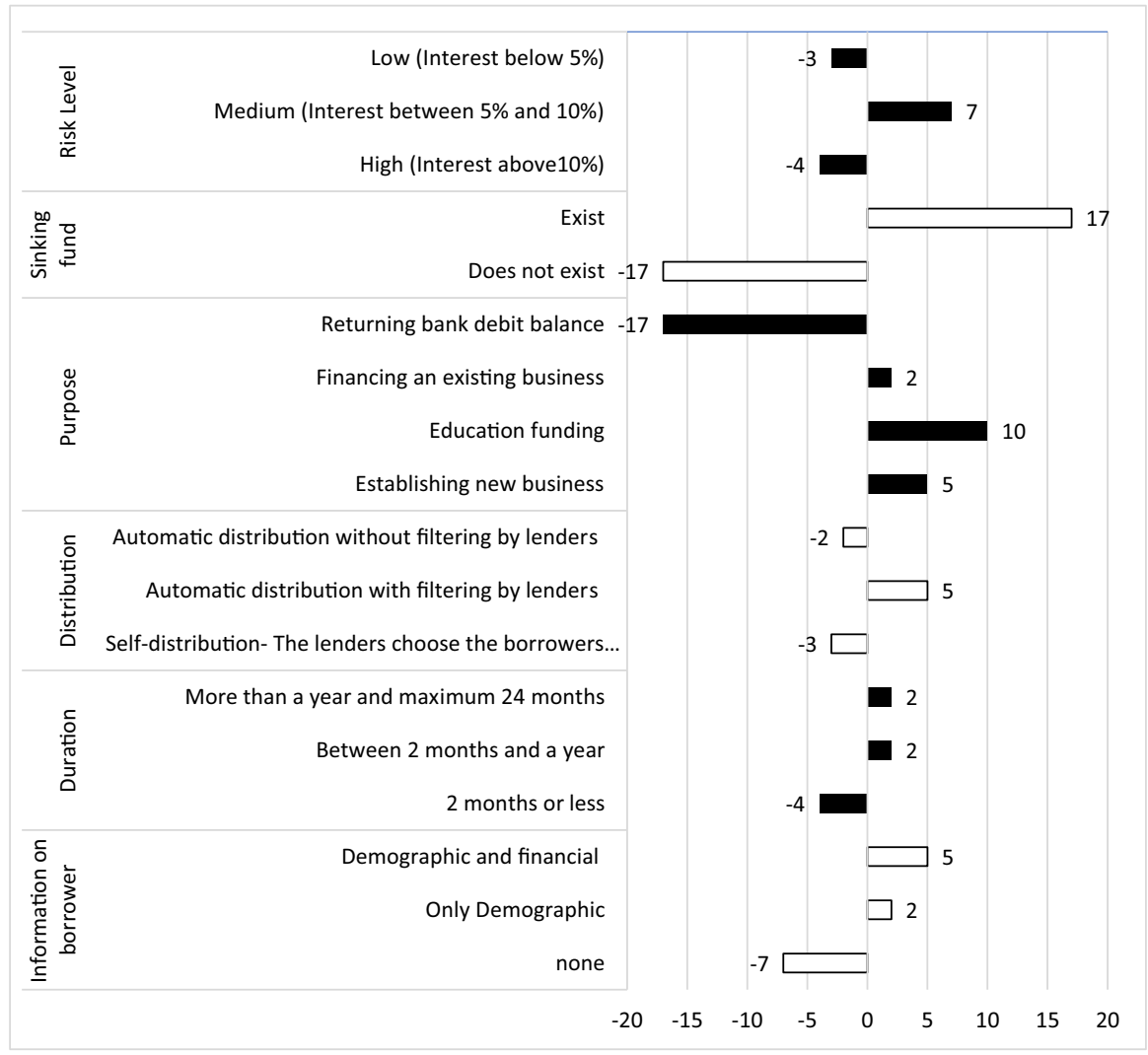

Fig. 3 Importance of loan attributes for lenders

about borrowers, including information about their financial condition, and avoided loans that did not reveal any information about them.

Comparing the non-users to the lenders shows that the non-users are more cautious about the possibility of lending money using P2P platforms. Differences were found regarding duration of the loan, with the non-users preferring short-term loans (up to 2 months) and low-risk loans with low interest rates. The non-users also preferred to refrain from investing in new businesses, but were found to be more open to lending for the purpose of returning financial debt. No differences were found in the direction or importance of the other levels and attributes.

\subsubsection{Attitudes about using P2P platforms}

Lastly, we measured the lenders' attitudes toward P2P platforms and their use thereof. The results are displayed in Table 2. On average, lenders who were willing to invest money in P2P platforms, were willing to lend an amount exceeding $\$ 35,000$ USD, which is far more than the maximum amount that borrowers are able 


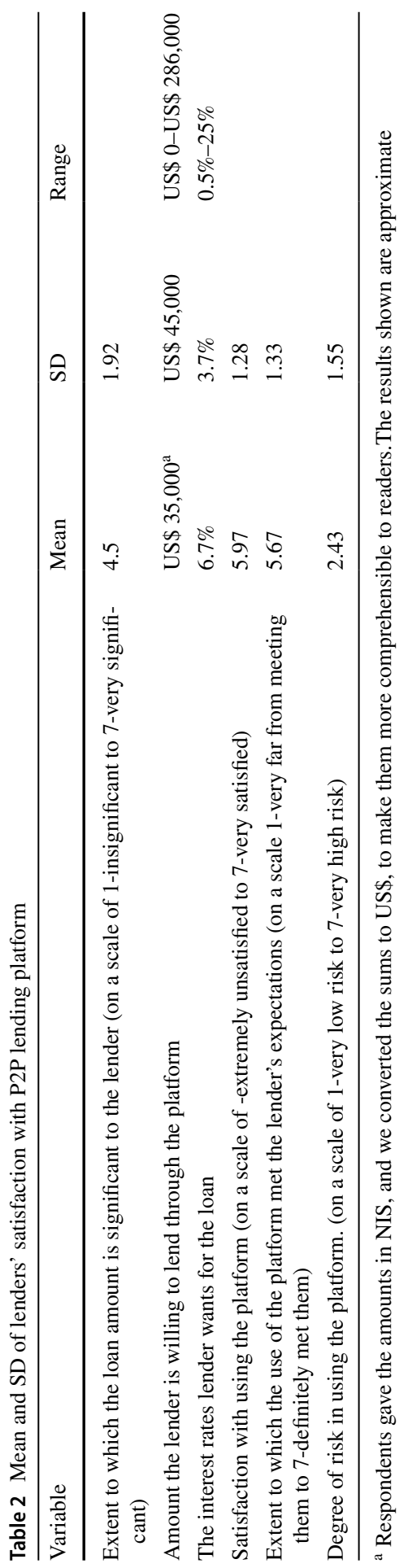


to request on these platforms $(\$ 14,000-\$ 20,000$ USD). On the other hand, the average interest rate they requested was $6.7 \%$, which is higher than the interest on saving accounts $(0.3 \%-1.7 \%),{ }^{4}$ but lower than riskier instruments, such as stocks (approximately $8 \%$ according to the Bank of Israel ${ }^{5}$ ). This interest rate indicates that lenders perceived the platform as being of medium-high risk, and therefore expected the company to compensate them for the risk taken. That said, lenders stated they felt the platform was safe, and agreed that it met their expectations, meaning they felt secure, and would be willing to lend higher sums through the P2P platforms in the future. Yet, they still required higher interest rates in order to motivate their choice to not go with more traditional financial tools. This implies that they still had doubts about the security of the P2P platform or its borrowers.

\section{Study 2: P2P companies' perspective}

In the second study, we focused on the dyadic relationship between companies and lenders, and the extent to which companies meet lenders' preferences compared to borrowers' interests. Since the first study indicated that lenders are looking for attributes that will secure their investment, we asked if the companies are attuned to the lenders' preferences. To investigate this question, we looked at the loan interest rate variable. The interest rate is solely determined by the companies; the lenders do not have any influence on the interest rates. Interest rates are determined according to different factors which the company deems important. Our main interest was to examine whether the companies also take into consideration the factors that are significant to the lenders-and above all, the reduction of risk.

\subsection{Methodology}

\subsubsection{Data}

Data was gathered from a public database published on the website of a P2P company (i.e., Eloan). The company allowed lenders to distribute their loans across a variety of offers. The data presented on the platform included the following: amount of the loan, the level of interest, the duration of the loan, and the purpose of the loan. The data also described the status of the loan. Loans can be "open"- the loan was given and the borrower is still paying off the loan each month. Loans can be "closed"- the loan has been given and the borrower has already paid off the loan. A third case scenario is that the loan is "in arrears"- the loan has been given but the borrower is not making his monthly payments to pay back the loan. In addition,

\footnotetext{
${ }^{4}$ Based on Bizportal data https://www.bizportal.co.il/capitalmarket/news/article/619815.

5 Bank of Israel report, (3.2018).

https://www.boi.org.il/he/NewsAndPublications/RegularPublications/DocLib3/BankIsraelAnnualRepo rt/\%D7\%93\%D7\%95\%D7\%97\%20\%D7\%91\%D7\%A0\%D7\%A7\%20\%D7\%99\%D7\%A9\%D7\%A8\%D7\% 90\%D7\%9C\%202017/page1.pdf.
} 
information about the borrower's demographic characteristics are also presented, but are limited by the need to maintain anonymity. The data included borrower's gender, marital status, number of children, number of providers in the family, family income, apartment ownership, education, degree, profession, employment status, and work seniority.

A sample of 500 requests for loans was created from approximately 5000 registered loans, using the systematic random sampling method. The first loan in the sample was chosen at random, and then the sample was collected by choosing every tenth loan, thereafter. The demographics and characteristics of the lenders and borrowers are described in Table 3.

\subsubsection{Variables}

4.1.2.1 Dependent variable . The interest determined by the company, in advance, and published on the platform for the loan request.

4.1.2.2 Independent variables Loan characteristics. We measured four variables that characterized the loan. Sum of the loan: The amount requested, which ranged between NIS 5,000 and NIS 60,000 with the average being NIS 21,418 (SD=12,328). The period of the loan, which ranged between 6 to 60 months, with the average being 36 months ( $\mathrm{SD}=15$ months). Status of the loan: in arrears ("0"), $8.3 \%$ of the total loans; open ("1"), 64\% of the loans; and closed ("2"), $27.7 \%$ of the loans. To measure whether a loan in arrears had unique features, we transformed this variable into a

Table 3 Definition of the loan and borrowers

\begin{tabular}{|c|c|c|c|c|}
\hline $\begin{array}{l}\text { Variables/catego- } \\
\text { ries and percent- } \\
\text { age }\end{array}$ & & & & \\
\hline Gender & $\begin{array}{l}\text { Male-66\% (330 } \\
\text { men) }\end{array}$ & $\begin{array}{l}\text { Female }-34 \%(170 \\
\text { women }\end{array}$ & & \\
\hline Marital status & Single $-23 \%$ & Married - $63 \%$ & Other- $-14 \%$ & \\
\hline Provider type & Solo provider $-40 \%$ & Two providers- $59 \%$ & $3+$ or other $-1 \%$ & \\
\hline Home ownership & Own a home- $57 \%$ & $\begin{array}{l}\text { Do not own a home- } \\
43 \%\end{array}$ & & \\
\hline Academic degree & $\begin{array}{l}\text { Do not have a college } \\
\text { education- } 54 \%\end{array}$ & $\begin{array}{l}\text { Bachelor's degree- } \\
33 \%\end{array}$ & $\begin{array}{l}\text { Master's } \\
\text { degree-13\% }\end{array}$ & \\
\hline \multirow[t]{2}{*}{ Work status } & Full-time- $86 \%$ & Part-time- $5 \%$ & Self-employed-7\% & $\begin{array}{l}\text { Not work- } \\
\text { ing-2\% }\end{array}$ \\
\hline & & \multicolumn{2}{|l|}{ Range } & Mean \\
\hline \multicolumn{2}{|l|}{ Num. of children } & \multicolumn{2}{|l|}{$0-8$ children } & 2 \\
\hline \multicolumn{2}{|l|}{ Income } & \multicolumn{2}{|c|}{$0-135,000$ NIS ( $\$ 38,500$ USD) } & $\begin{array}{l}14,334.67 \\
\text { NIS }(\$ 4,100 \\
\text { USD) }\end{array}$ \\
\hline Tenure & & \multicolumn{2}{|l|}{$0-10$ years } & 5.32 years \\
\hline
\end{tabular}


dummy variable: loan in arrears ("1") and otherwise ("0"). The last variable, purpose of the loan, appeared as a text. Thus, we sorted the data into 10 different categories, which we later transformed into six dummy variables based on common utility and number of borrowers ("1" - the type of purpose, and "0"-otherwise). The categories included ("1") debt repayment loan/overdraft, ("2") apartment renovation, (“3") purchase of goods, ("4") events, ("5") business investments, and ("6") other.

The Borrower financial condition. The borrowers' financial condition is usually made known to the investors by displaying a credit score (i.e., FICO ${ }^{\circledR}$ ). However, Israel has only just recently established a credit score system; therefore, the borrowers' credit scores were not published in the P2P platform. However, in their extensive review Bachmann et al. [2] argue that "Typical financial characteristics are credit ratings, detailed information on income and monthly expenses, houseownership or the debt to income ratio" (p. 8). As such, we controlled part of the financial condition based on the borrower's income (on a scale from 1 -extremely beneath the average income to 5-highly above the average income) and home ownership ("0"- no, " 1 "- own). In addition, while we do not have information regarding the borrower's financial state, the companies do have such data and use them to assign the loan to the appropriate credit profile [30], e.g., category "A" loans indicate low-risk borrowers (and low-risk loans), while category E signals a high-risk borrower. As such, we controlled the loan category by measuring the risk of the loan with three dummy categories: A/B-low-risk loans; $\mathrm{C}$-medium-risk loans; and $\mathrm{D} / \mathrm{E}$ - high-risk loans (category D or E). Despite using the credit score signal on the amount of the borrows' financial risk, it is still just a proxy for the borrowers' credit history and previous lending behaviors.

Demographic variables. We also included some demographic variables: Gender ("0"-male; "1"-female), marital status ("1"-married, "0"-other), seniority at work, work status (" 1 "- full time; " 0 "—other), self-employed (" 1 " - self-employed, " 0 "- other), number of providers (" 0 " - solo, " 1 " -2 or more), degree (" 0 "—no degree, " $1 "$ - academic degree).

\subsection{Results}

\subsubsection{Distribution of loan purpose}

Our main interest was to examine what influences the interest rate, other than the borrowers' financial condition, and whether companies consider lenders' preferences, as was found in the first study. To examine these questions, we first analyzed the distribution of loans by purpose, as initially listed on the company website. The distribution is depicted in Fig. 4.

The distribution shows that the most common purpose was financing overdraft coverage, and that $33 \%$ of borrowers applied for a loan whose purpose was to close an overdraft or repay a bank debt. A total of $44 \%$ of the loans were taken by borrowers who requested loans to repay a bank debt plus those wishing to recycle their credit debts. In addition, $14 \%$ of borrowers requested loans for home renovations 


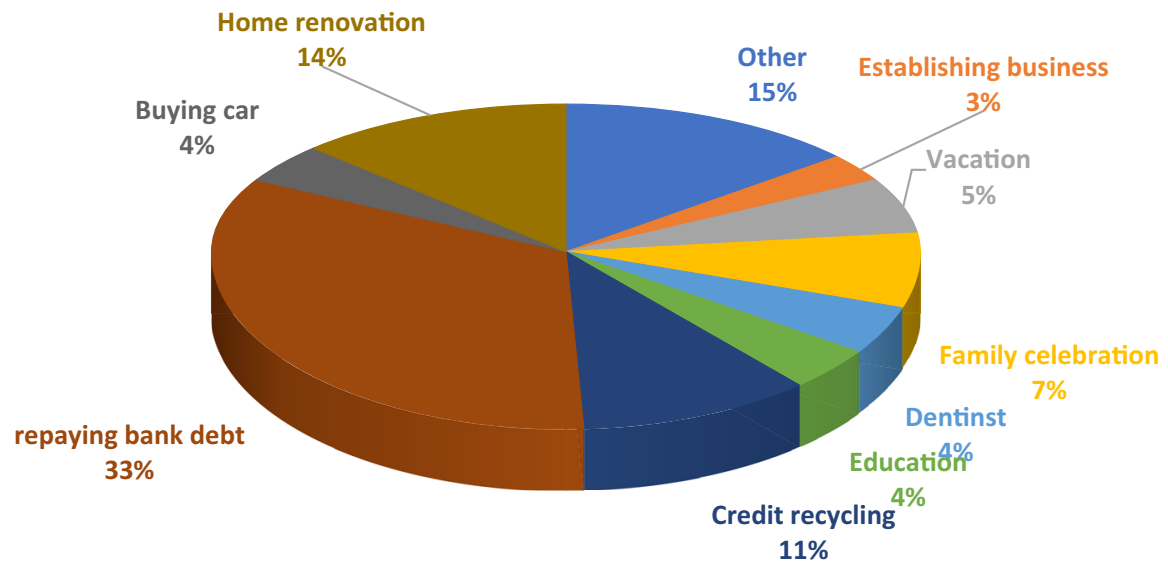

Fig. 4 Distribution of loans by purposes

and $7 \%$ to finance a family event (e.g., a wedding), indicating that most of the borrowers used loans for daily purposes, rather than to create future wealth, such as establishing a new business or acquiring higher education. Comparing this to the results of the conjoint analysis in Study 1, we found a discrepancy between the lenders' preferences and the type of loans available on the platforms. Lenders preferred not to invest in loans intended to repay bank debits, but rather preferred loans whose purpose was education or to support new and established businesses. The results therefore indicate that the platforms do not necessarily reflect or consider the lenders' preferences.

\subsubsection{Factors influencing the interest rate}

To examine our second hypothesis we first performed a correlation analysis, in order to analyze the independent variables. The correlation matrix appears in "Appendix A". The results of the correlation analysis as well as the IVF test (as appear in Table 4) indicate that the variables did not suffer from multiclonality, except for the variable "loan purpose-other", which had a high VIF score (0.97); thus, it was removed from the regression analysis.

Next, we conducted several regression analyses to examine the factors that impact the loan interest rate. Table 4 exhibits the different regression models.

In Model 1, we measured the connection between the loan terms and the interest rate. The result shows that the amount requested and the period of the loan together contribute $26.6 \%$ to the overall variance. This means that both the amount of the loan and the period of the loan influence the interest rate, which signal the loan's risk level. Longer-term loans were compensated by higher interest rates $(\beta=0.207$, $p<0.01)$. Surprisingly, the amount requested had a negative connection with the loan's interest rate $(\beta=-0.617, p<0.01)$, i.e., the higher the sum, the lower the interest rate. 


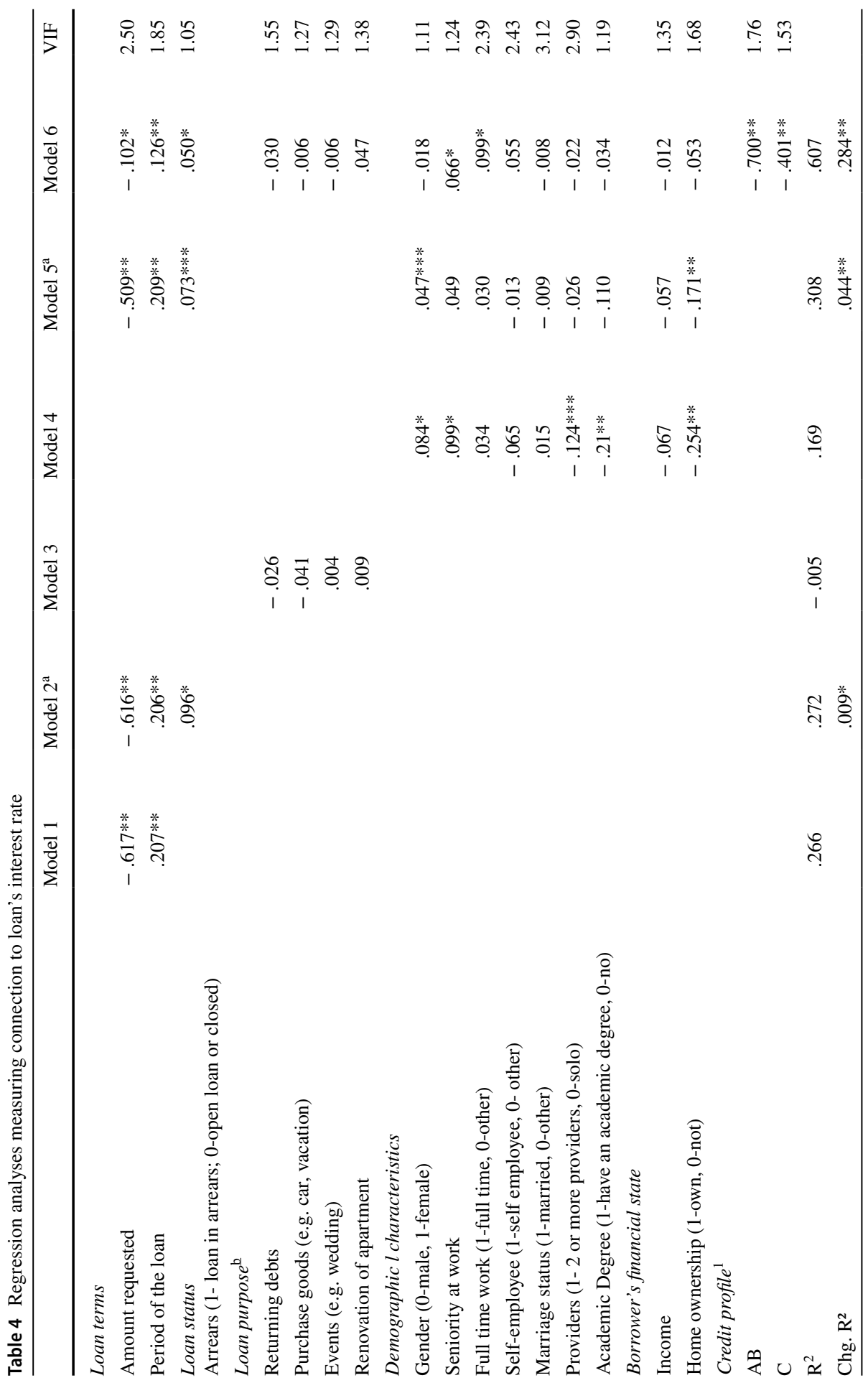




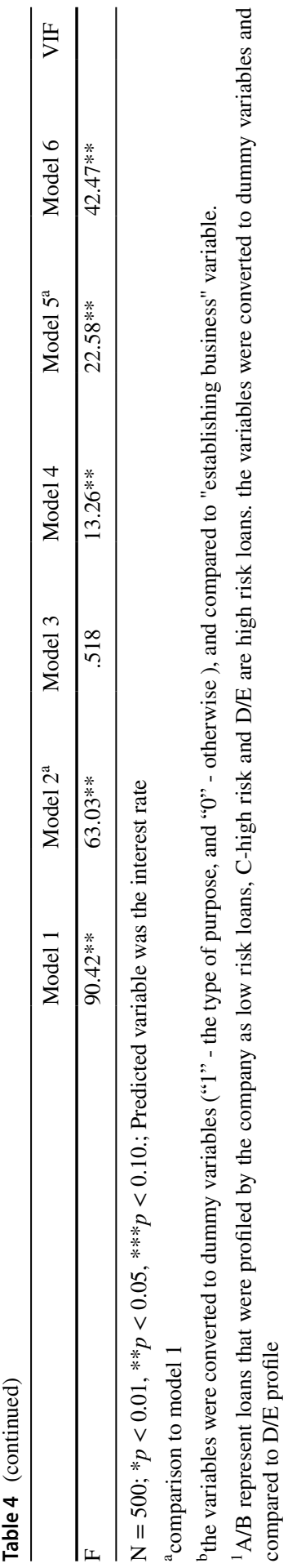


In Model 2, we included loan status and found that it makes a unique contribution to the interest rate over the terms of the loan (Chg. $\mathrm{R} 2=9 \%, p<0.05$ ). The direction was positive $(\beta=0.096, p<0.05)$, meaning that loans in arrears had a higher interest rate, which indicates that the company understood, in advance, that these loans were riskier. Therefore, they compensated for the potential hazard with higher interest.

Model 3 measured the connection between the purpose of the loan and its interest rate. We measured loan purpose, comparing business investments with other returning debts' variables. However, the regression results show that loan purpose did not have a significant relationship with the interest rate. The results imply that the company did not take loan purpose into consideration when determining the interest rate.

Entering the demographic characteristics and the borrower's financial state (Model 4) reveals that higher interest correlates with women, employees with more seniority, borrowers that are solo providers, borrowers without an academic degree, and borrowers who do not own a home. However, when we added the loan terms and the loan status (Model 5), only two demographic variables contributed to the total variance over the loan terms: home ownership and gender, which was close to significance $(\beta=0.047, p<0.10)$. We found that borrowers who did not own their home and women paid higher interest rates for their loans. Nevertheless, the main factor contributing to interest rate is still the loan terms, and especially the amount requested $(\beta=-0.509, p<0.01)$. Therefore, we conclude that while demographic variables had some effect on the interest rate, companies determine interest rates based on the amount of the loan and the period of return.

Finally, in the last regression analysis (Model 6) we controlled the loan credit profile, in addition to the independent variables. We used the credit profile as a proxy for the borrowers' credit history and previous lending, which were not provided by the platform. Compared to the riskiest loans (category D/E is omitted), both profiles $(\mathrm{A} / \mathrm{B}$ and $\mathrm{C})$ were found to significantly contribute to the interest rate. Meaning, loans with the lowest risk $(\mathrm{A} / \mathrm{B})$ received the lowest interest rates $(\beta=-0.70$, $p<0.01$ ), while loans that were profiled as medium risk $(C)$ were also negatively correlated, albeit to a lesser degree, compared to high-risk loans $(\beta=-0.401$, $p<0.01)$. In addition, we also found that the sum of the loan and the loan period continue to be significantly connected to the interest rate. The sum of the loan was found to be negatively connected, meaning that the higher the sum of the loan the lower the interest rate, indicating that $\mathrm{P} 2 \mathrm{P}$ companies encourage borrowers to take higher-risk loans. Moreover, findings show that loan purpose was still insignificantly connected to the interest rate, clearly indicating that the companies do not differentiate between loans taken for investment purposes (i.e., establishing a business) and loans taken to return debts. As such, the results confirm our second hypothesis to some degree, suggesting the existence of a discrepancy between the investors' desires and the motivation of the $\mathrm{P} 2 \mathrm{P}$ companies. 


\section{Discussion}

The results of the study highlight the discrepancy between lenders' preferences and the behavior of P2P companies. It seems that the companies are more interested in attracting borrowers, even at the expense of not meeting lenders' expectations. This gap may explain the minor share of P2P platforms in the lending industry [29]. The minor share affects the slow competition in the lending sector, and reduces the potential to benefit customers, unlike the competition in other financial sectors, e.g., payment card and credit markets [25].

The results of the first study show that lenders prefer security over high profits. The most important attribute for lenders was the existence of security sinking funds, which guarantee to repay the invested capital in case the borrowers default on their loans. This dimension also had the highest utility for the non-users, indicating that peer loan platforms are considered a high-risk instrument by both lenders and the non-users. Indeed, previous studies [28] found that lenders' willingness to continue using the platforms is due, in part, to the degree of confidence they have that borrowers will meet their obligations, as well as the sense of risk in using the platform. The lower the perceived risk level is, the greater the willingness to reinvest through the platform [6]. In the interviews we conducted with the company executives, the interviewees stated that they provide lenders with several tools, if the borrower is late in repaying the loan. However, very few of these tools offer a security fund that returns the lending sum in the case of non-repayment. The rest of the companies mostly provide legal aid to the lenders, thereby missing the most valuable attribute for lenders and the non-users.

The second most important attribute was purpose of the loan. While lenders were willing to authorize loans for the pursuit of higher education, the establishment of a new business, and even the financing of an existing business, they prefered to avoid loans taken in order to repay debts. The first three purposes have the potential to create future profits and progress. On the other hand, repaying financial debts not only does not guarantee potential revenue, it also signals a history of risky financial behavior. However, most of the loans available to lenders are intended to pay off debts, finance renovations, or purchase products and services-none of which have the potential for future profits, and all of which may signal potentially risky financial behavior $[11,15]$. This pattern is consistent with the distribution pattern found by the Lending Club - one of the largest P2P platforms in the US [20]. Researchers reported that the main purposes for taking loans were returning debt (44.6\%), credit card payment (13\%), home renovation (7\%), and to cover large purchases $(6.5 \%)$, while loans for small business development accounted for only $4.3 \%$. Therefore, the data obtained in Israel indicates a pattern similar to that found in other countries.

Considering the potential risk embedded in taking loans in order to return debt or purchase goods, we would have expected that the purpose of the loans would have an impact on the interest rate. However, according to the regression analysis performed 
in Study 2, it appears that the purpose of the loan had no effect on the interest rate level, even when the purpose signals a high risk, as in the case of refinancing debts. The lenders' interest in reducing risk was also evident from their preferences regarding interest rates and loan periods. Both attributes were less important for lenders compared to sinking funds and the purpose of the loan. We found that most lenders were interested in medium-risk loans, with interest rates ranging from $5 \%$ to $10 \%$, and loans that are granted for longer than one year. The average interest rate preferred by lenders was $6.7 \%$, which is higher than the rates of short-term deposits or savings accounts, but lower than riskier investment instruments, such as the stock market. This finding is incongruent with previous research, which argued that lenders prefer to invest in high-risk loans, characterized by large amounts and high interest rates [9]. This may indicate that lenders do not trust the ability of P2P platforms to guarantee their investments, or the readiness of borrowers on these platforms to meet their obligations to lenders.

\section{Conclusions and implications}

Our study started with the question of why P2P lending platforms have such a small market share. One reason may be the gap between the lenders' desire to decrease their risk with a guarantee that their investment is secure, and the behavior of the companies. The current study shows that P2P companies encourage borrowers, thereby increasing the risk inherent in lending money to strangers. This pattern could explain the negative connection we found between the amount of the loan and the level of interest rates. While former studies argued that larger amounts are a greater risk to lenders [4], we found that companies actually encourage borrowers to borrow large amounts by reducing the interest rate. This indicates a lack of connection between the companies operating in the P2P industry and their lenders' needs.

The contradiction between the lenders and the companies is unspoken, but can still impact on the future of the P2P lending industry. One of the inherent failures in providing loans to strangers is the asymmetric information and the moral hazard problem [2]. The problem of asymmetric information occurs in a situation wherein one party in the transaction has more or better information about the transaction than the other [2]. In our case, lenders need to trust the readiness of the P2P company to protect their investment, since they do not know to whom they are lending their money. Former studies found that trust is a major constraint in the financial system [26]. Trust is especially necessary for high-risk financial instruments and affects behavioral economic decisions [15, 22]. Therefore, by encouraging the borrowers at the expense of the lenders, the companies expose the latter to higher risk, and reduce their readiness to invest through these platforms. To overcome this failure, companies should reduce the lenders' concerns by addressing their fear of economic risk by, for example, establishing a sinking fund that would refund their money if 
the borrowers fail to meet their obligations. In addition, companies must provide better matches between lenders' preferences and the actual loans requested-even when lenders choose to use an automatic dispersal mechanism. If this adjustment is not possible, high-risk loans (such as repayment of debt) must be compensated with higher interest rates.

We also found that the non-users perceive the P2P platforms to be a high-risk instrument. Therefore, they consider sinking funds to be the most important factor affecting their decision to invest through $\mathrm{P} 2 \mathrm{P}$ platforms. The second-most important factor was the interest rate, which indicates the need for high compensation if they decide to invest in this platform. Indeed, Zwilling, Klein and Shtudiner [32] found that $\mathrm{P} 2 \mathrm{P}$ platforms suffer from a lack of legitimacy in the eyes of the nonusers, which results in an unwillingness to invest through $\mathrm{P} 2 \mathrm{P}$ platforms. Therefore, $\mathrm{P} 2 \mathrm{P}$ companies must take into consideration the desires of the non-users and provide tools that will protect them from losses, such as sinking funds. Otherwise, the P2P sector will continue to be only a minor player in the lending sector.

Another option is to perceive P2P platforms as high-risk financial instruments, and raise interest rates to signal that the investment through a $\mathrm{P} 2 \mathrm{P}$ platform is an alternative to investing in the stock market or foreign exchange market. Yet another option would be to allow bidding on loan auctions, in which interest rates are determined according to supply and demand, based on the attractiveness of the loans. This will provide higher compensation for riskier loans, by providing better interest rates for the lenders.

\subsection{Limitation and future studies}

It is important to point out that this study has several limitations that should be taken into consideration. Primarily, we had difficulties in obtaining lenders' cooperation. Although we sent our request with the assistance of the largest P2P company in Israel, the response rate was low, which could jeopardize the validity of generalizations drawn from the current results. Furthermore, our findings and respective conclusions apply to the data received from the major P2P platform company in Israel. It is reasonable to assume that these findings may differ among different global financial markets around the world, so P2P practitioners should regard these findings with caution. This argument is just as important as the generalizability of the study's impact. As previously mentioned, P2P lending platforms in Israel occupy only a tiny portion in the finance industry. Therefore, when applied to different global markets and economic environments - in which laws, regulations, and cultural habits might differ-it is possible to find diverse attitudes and behaviors among lenders and borrowers. Yet, this study shows that the discrepancies between lenders and P2P companies can affect the development of the P2P industry. Moreover, the mutual trust of lenders in the P2P platform should be addressed and improved in 
a way that will provide lenders with tools and opportunities that can reduce their risk-either through, for example, "sinking funds" or recommendations that better match their preferences with those of the actual loaners.

In addition, while the first and second studies investigated different populations, the inconsistency between the conjoint analysis findings and the sample collected from a real P2P platform, could be a result of the differences in the number of the subjects. Moreover, to overcome the obstacle of a small number of subjects, future studies are recommended to utilize data mining tools, which are prevalent in such cases where the number of respondents is relatively small [19]. Therefore, future studies are needed to strengthen the research results.

Another difficulty was the evaluation of factors affecting the interest rate. The interviews we conducted with senior executives and founders of P2Ps indicate that their main concern was the borrowers' financial condition. To measure the effect of other factors, we needed to gain access to data on the borrowers, but all of the companies we asked refused to give us access to their database, since they considered it their main core asset. As such, our ability to truly analyze the effect of other factors should be augmented by future studies that can gain access to more information.

In summary, although the share of the P2P platform remains small, we believe that these platforms constitute an appropriate alternative to traditional banking systems, both as a relatively solid investment channel, and as a way to obtain loans with convenient terms. At the same time, companies in the industry must make further attempts to increase lenders' trust, and reduce feelings of risk associated with using the platform. Failing to reduce the moral hazard problem will harm the chances of this instrument being able to offer real competition in an industry that suffers from market failure. 


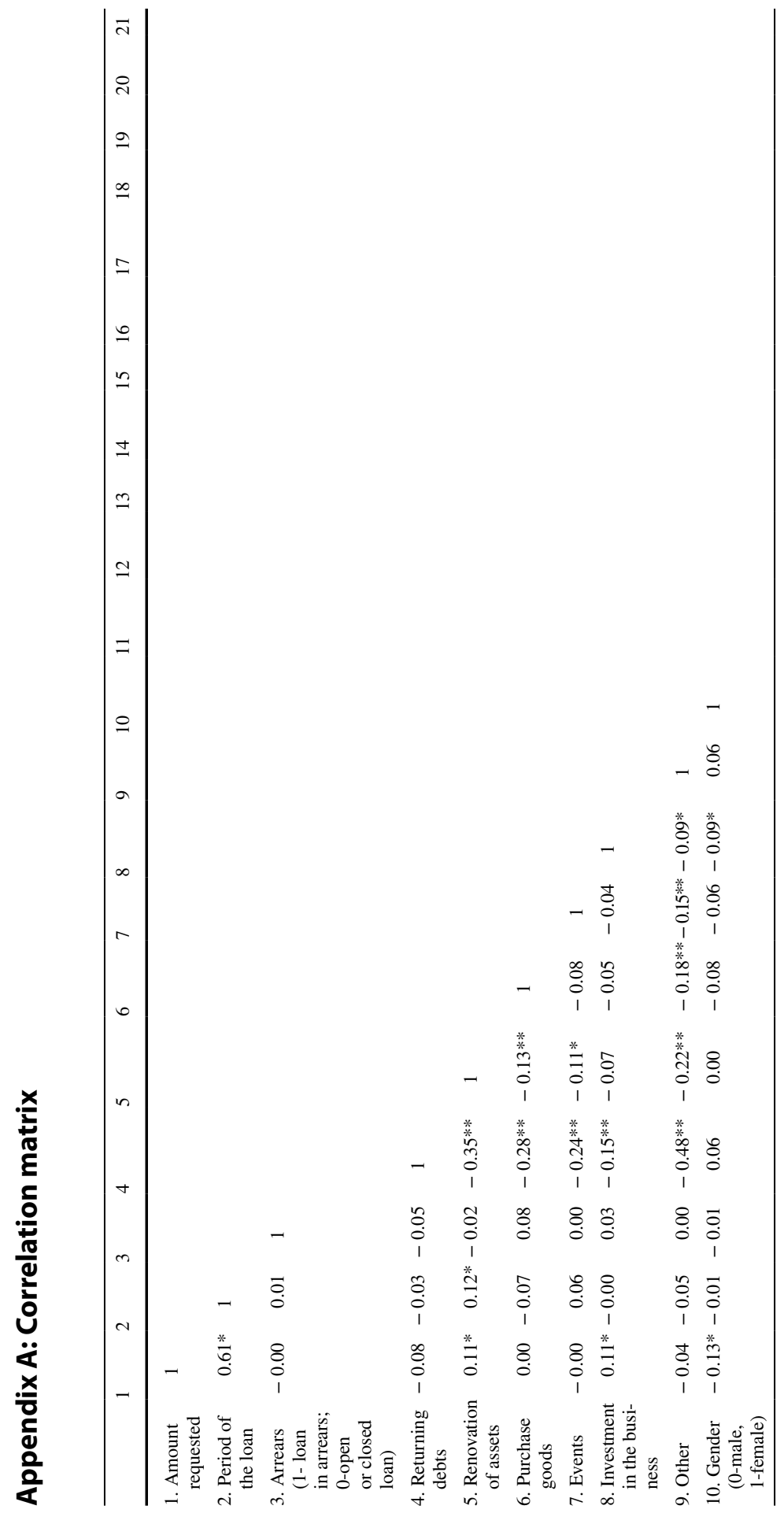




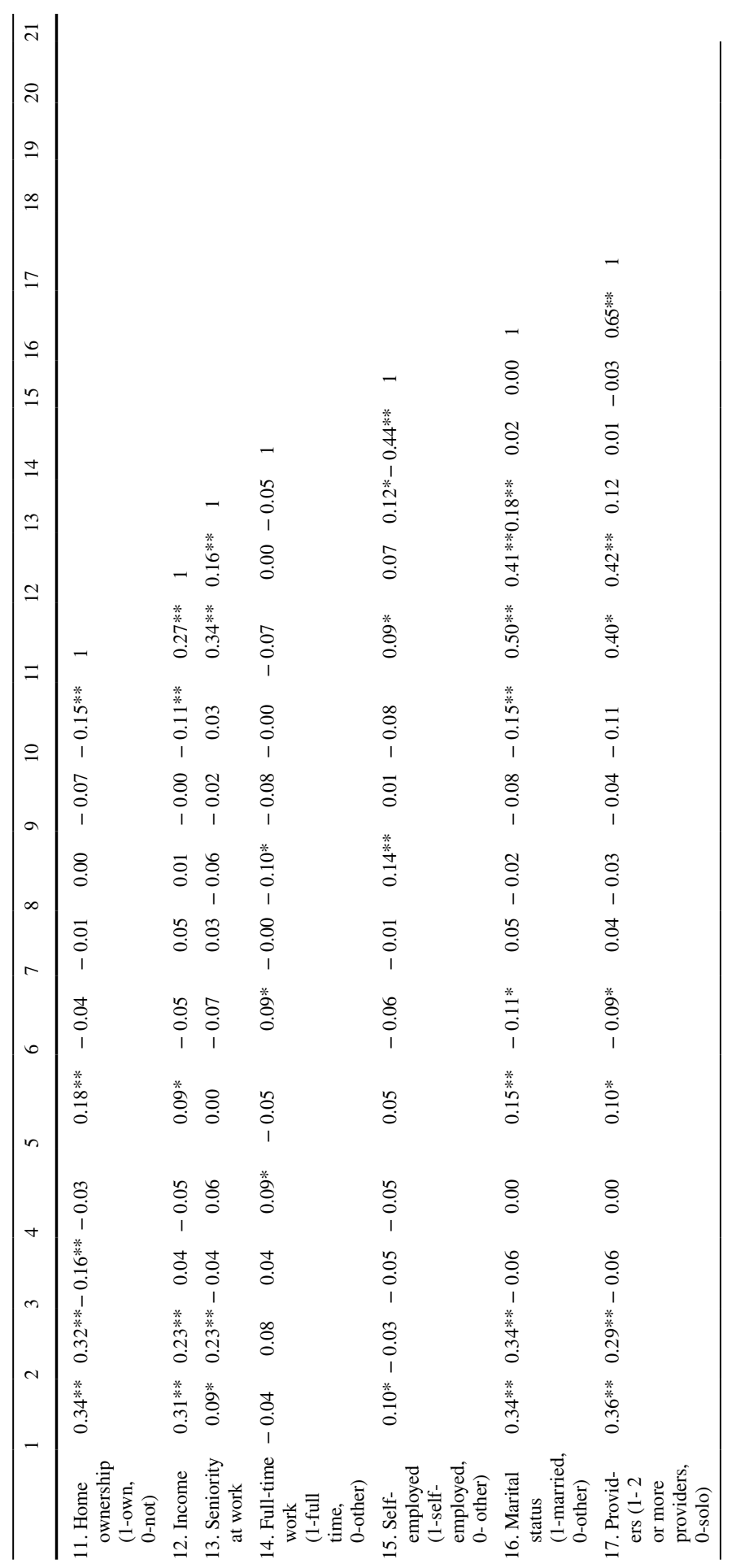




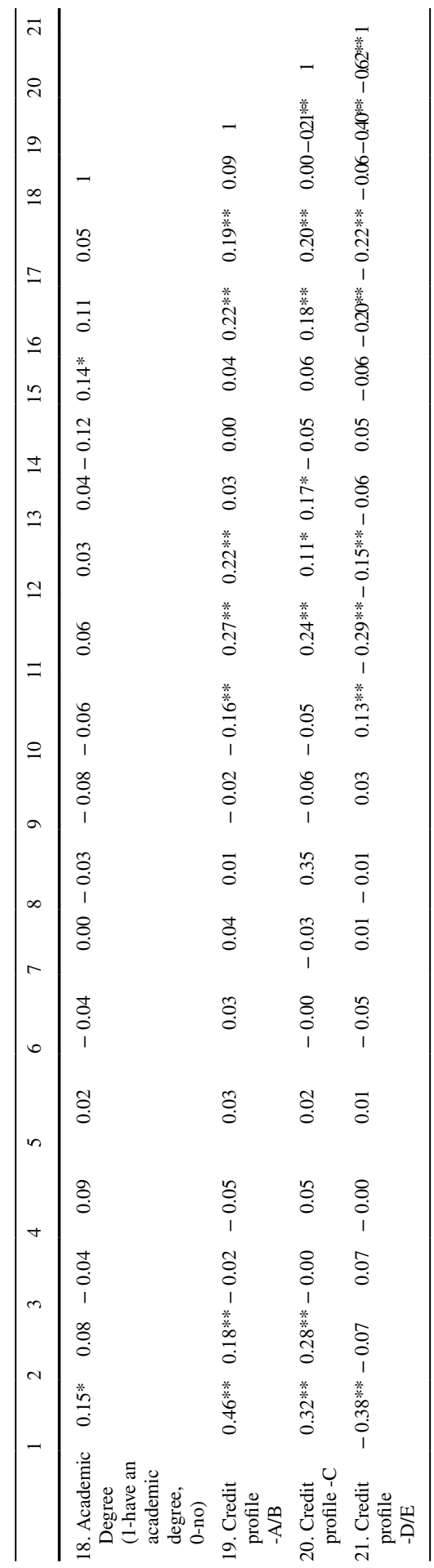


Supplementary Information The online version contains supplementary material available at https://doi. org/10.1007/s10660-021-09489-6.

Acknowledgements This work was supported by The Heth Academic Center for Research of Competition and Regulation. We would like to thank the reviewers and the editor for helping us improve the paper.

Funding This work was supported by the Heth Academic Center for Research of Competition and Regulation] under Grant RA1700000423.

\section{Declarations}

Conflict of intrest This work was supported by The Heth Academic Center for Research of Competition and Regulation.

\section{References}

1. Aleksynska, M., \& Havrylchyk, O. (2013). FDI from the south: The role of institutional distance and natural resources. European Journal of Political Economy, 29, 38-53.

2. Bachmann, A., Becker, A., Buerckner, D., Hilker, M., et al. (2011). Online peer-to-peer lending-a literature review. Journal of Internet Banking and Commerce, 16(2), 1-17.

3. Capelle-Blancard, G., \& Havrylchyk, O. (2017). Incidence of bank levy and bank market power. Review of Finance, 21(3), 1023-1046.

4. Chen, X. H., Jin, F. J., Zhang, Q., \& Yang, L. (2016). Are investors rational or perceptual in P2P lending? Information Systems and e-Business Management, 14(4), 921-944.

5. Duarte, J., Siegel, S., \& Young, L. (2012). Trust and credit: The role of appearance in peer-to-peer lending. The Review of Financial Studies, 25(8), 2455-2484.

6. Gao, Y., Yu, S. H., \& Shiue, Y. C. (2018). The performance of the P2P finance industry in China. Electronic Commerce Research and Applications, 30, 138-148.

7. Green, P. E., Krieger, A. M., \& Agarwal, M. K. (1991). Adaptive conjoint analysis: Some caveats and suggestions. Journal of Marketing Research, 28(2), 215-222.

8. Greenberg, D., \& Shtudiner, Z. (2016). Can financial education extend the border of bounded rationality? Modern Economy, 7(2), 103-108.

9. Havrylchyk, O., \& Verdier, M. (2018). The financial intermediation role of the P2P lending platforms. Comparative Economic Studies, 60(1), 115-130.

10. Hidayat, A. S., Alam, F. S., \& Helmi, M. I. (2020). Consumer protection on peer to peer lending financial technology in Indonesia. International Journal of Scientific and Technology Research, 9(1), 4069-4072.

11. Hilgert, M. A., Hogarth, J. M., \& Beverly, S. G. (2003). Household financial management: The connection between knowledge and behavior. Federal Reserve Bulletin, 89, 309-322.

12. Klafft, M. (2008, March). Peer to peer lending: auctioning microcredits over the internet. In Proceedings of the International Conference on Information Systems, Technology and Management, A. Agarwal, R. Khurana, (Eds)., IMT, Dubai.

13. Klein, G. (2016). Different thinking or similar models: do entrepreneurs and franchisees apply the same decision-making models prior to establishing a company? Journal for International Business and Entrepreneurship Development, 9(3), 342-357.

14. Klein, G. (2016). Trying to make rational decisions while employing intuitive reasoning: a look at the due-diligence process using the dual-system reasoning model. International Journal of Entrepreneurship and Innovation Management, 20(3-4), 214-234.

15. Klein, G., \& Shtudiner, Z. (2016). Trust in others: Does it affect investment decisions? Quality \& Quantity, 50(5), 1949-1967.

16. Liu, D., Brass, D. J., Lu, Y., \& Chen, D. (2015). Friendships in online peer-to-peer lending. Mis Quarterly, 39(3), 729-742.

17. Milne, A., \& Parboteeah, P. (2016). The business models and economics of peer-to-peer lending. 
18. Mariotto, C., \& Verdier, M. (2015). Innovation and competition in internet and mobile banking: An industrial organization perspective. Communication and Strategies, 99, 129-146.

19. Natek, S., \& Zwilling, M. (2014). Student data mining solution-knowledge management system related to higher education institutions. Expert Systems with Applications, 41(14), 6400-6407.

20. Pope D. G., \& Sydnor J.R. (2011) What's in a picture? Evidence of discrimination from prosper. com. Journal of Human Resources; 46(1):53-92.

21. Ravina, E. (2008). Love \& loans: The effect of beauty and personal characteristics in credit markets. Working paper, Columbia University, New York.

22. Serrano-Cinca, C., Gutiérrez-Nieto, B., \& López-Palacios, L. (2015). Determinants of default in P2P lending. PloS one, 10(10), e0139427. https://doi.org/10.1371/journal.pone.0139427https://doi. org/10.1371/journal.pone.0139427

23. Shen, D., Krumme, C., \& Lippman, A. (2010). Follow the profit or the herd? Exploring social effects in peer-to-peer lending. In 2010 IEEE Second International Conference on Social Computing (pp. 137-144). https://doi.org/10.1109/SocialCom.2010.28

24. Shen, F., \& Luo, N. (2016, June). Investment pattern clustering based on online P2P lending platform. In 2016 IEEE/ACIS 15th International Conference on Computer and Information Science (ICIS) (pp. 1-6). https://doi.org/10.1109/ICIS.2016.7550754

25. Shtudiner, Z., Klein, G., Zwilling, M., \& Kantor, J. (2019). The value of souvenirs: Endowment effect and religion. Annals of Tourism Research, 74, 17-32.

26. Shtudiner, Z., Zwilling, M., \& Kantor, J. (2017). Did I make the right decision? Attributes that influence people choice of city of residence. Review of Urban \& Regional Development Studies, 29(2), $103-113$.

27. Shtudiner, Z., Zwilling, M., \& Kantor, J. (2017). Field of Study Choice: Using Conjoint Analysis and Clustering. International Journal of Educational Management, 31(2), 179-188.

28. Verdier, M. (2011). Interchange fees in payment card systems: A survey of the literature. Journal of Economic Surveys, 25(2), 273-297.

29. Yan, Y., Lv, Z., \& Hu, B. (2018). Building investor trust in the P2P lending platform with a focus on Chinese P2P lending platforms. Electronic Commerce Research, 18(2), 203-224.

30. Zhao, H., Ge, Y., Liu, Q., Wang, G., Chen, E., \& Zhang, H. (2017). P2P lending survey: platforms, recent advances and prospects. ACM Transactions on Intelligent Systems and Technology (TIST), $8(6), 1-28$.

31. Zhang, J., \& Liu, P. (2012). Rational herding in microloan markets. Management Science, 58(5), 892-912.

32. Zwilling, M., Klein, G., \& Shtudiner, Z. (2020). The question of Peer-to-Peer lending platforms' legitimacy in the eyes of the general public and lenders. Israel Affairs, 26(6), 854-874.

Publisher's Note Springer Nature remains neutral with regard to jurisdictional claims in published maps and institutional affiliations. 